\title{
RELATIONSHIPS BETWEEN MANDIBULAR JOINT SIZE AND CRANIOFACIAL SIZE IN HUMAN GROUPS
}

\author{
R. J. Hinton \\ Department of Anatomy and Center for Human Growth and Development. \\ The University of Michigan, Ann Arbor, MI 48109. U.S.A.
}

\begin{abstract}
Summary-Substantial evidence attests to the capability of the joint to undergo morphological alteration in response to biomechanical forces transmitted to it during function. Measurements expressing the size of mandibular condyles and fossae were obtained from skulls representative of a broad spectrum of subsistence practices and tooth use. Craniofacial dimensions were measured for some groups. Considerable differences in joint size were noted between groups roughly consistent with known or presumed intensity of masticatory stress. Size was largest in the hunter-gatherers, intermediate in aboriginal horticulturalists and smallest in 20th century American caucasoids and 17 th century British. In each group, male joint size was absolutely larger than females. With the exception of condylar breadth, male joint dimensions were not relatively larger than female when corrected for differences in craniofacial size. In contrast, same-sex comparisons of Eskimo and American caucasoid means adjusted for differences in craniofacial size showed joint size in Eskimos to be significantly larger, both absolutely and relatively. Eskimo females had relatively larger joints than American caucasoid males. Thus, intergroup differences in joint size persist even when differences in craniofacial size are taken into account. Although the influence of genetic factors cannot be excluded, differences in the nature or intensity of tooth use during growth may account, at least in part, for the observed differences in joint size.
\end{abstract}

\section{INTRODUCTION}

Because of the complexities of articulation and movement introduced by its morphology and its connections to the dentition, the human mandibular joint (MJ) is a focal point for discussion and debate. There is increasing evidence that some force is transmitted to the human joint during function. Long suspected on the basis of histological studies (Sicher, 1952; Rees, 1954; Moffett et al., 1964; Scheman, Milstoc and Rubin, 1974) and biomechanical analyses (Barbenel, 1969, 1972; Hylander, 1975; Smith, 1978), in-vivo measurements of bone strain in the subcondylar region of the lower jaw of macaque monkeys (Hylander, 1979) confirm forces at the macaque $\mathrm{MJ}$ to be of considerable magnitude during mastication and incisal biting.

Although the possible effects of functionallyinduced stresses on joint morphology are not well understood. orofunctional factors may influence the growth of the MJ. Experimental investigations of growing monkeys and other laboratory animals have shown that the joint, far from being an independent or intrinsic growth centre, is a site of compensatory or adaptive growth which can occur in response to disturbances in occlusion that alter the biomechanical environment of the joint (Stöckli and Willert, 1971; McNamara, 1972; Petrovic, Stutzmann and Oudet, 1975; Simon. 1977; McNamara and Carlson, 1979) or to alterations in masticatory muscle orientation and utilization that takes place during normal craniofacial growth (Carlson, McNamara and Jaul, 1978). Although such changes have been investigated experimentally only in (sub-adult) animals, examination of human skulls (Mongini, 1972; Seward, 1976: Wedel. Carlsson and Sagne 1978; Granados, 1979: Hinton, 1981a,b) and human cadaveral material (Moffett et al., 1964; Oberg. Carlsson and Fajers, 1971) suggest that joint contours may continue to change in response to tooth attrition or tooth loss throughout life.

However, growth in size of the joint appears to cease, at least in the condyle, by the late teens or early twenties (Rushton, 1944; Moffett, 1966; Scott and Symons, 1974; Wright and Moffett, 1974), by which time the condylar cartilage has been almost entirely replaced by bone. Presumably a similar timing is true of the temporal joint component, although considerably less information is available concerning the duration and nature of its growth (Hinton, 1981a). Although information is sparse concerning the adaptability of joint size during growth, a number of experimental studies have demonstrated larger condylar dimensions in rats fed a diet of coarse consistency when compared with controls fed a diet requiring little strenuous mastication (Watt and Williams, 1951: Barber, Green and Cox, 1963; Moore, 1965; Beecher and Corruccini, 1981). As there are great differences among human groups in diet and the magnitude of forces which are routinely applied to the dentition (cf. Molnar, 1972), it could be supposed that relative levels of orofunctional stress might be reflected in differential size of the human joint. Although no systematic comparisons have been made, the available data suggest that intergroup differences in joint size may indeed exist. The largest condylar dimensions are in fossil hominids (Wolpoff, 1975; Smith, 1976; White, 1977), but there are indications of appreciable variability among living human groups also (Wallace. 
1927; Dingwall and Young. 1933; Weidenreich, 1936). For the temporal joint component, considerable differences in size among extant human groups have been documented, the largest dimensions being in hunting and gathering peoples (Moffett, 1968; Oberg, Carlsson and Fajers, 1971). The size of the temporal component may be secondary to that of the condyle (Hinton and Carlson, 1979) but the two joint components are probably closely linked during development (Kazanjian, 1939), resulting in congruence between the condyle and mandibular fossa (Van Lile, 1954; Lindblom, 1976). Thus, the size of both structures is probably related to severity of orofunctional stimuli, although condylar size presumably provides the more direct estimate of adaptational response to biomechanical forces.

There are, however, indications that joint size is correlated to some extent with the overall size of the cranium and face (Demirjian, 1967; Wedel et al., 1978). Accordingly, analysis of intergroup differences in joint size must take into consideration the possibility that the differences that exist may represent disparities in craniofacial size among the groups studied. My aim was to evaluate quantitatively intergroup differences in MJ size and to examine the relationship of joint size dimensions to selected parameters of craniofacial size.

\section{MATERIALS AND METHODS}

The mandibular fossa and condyle were measured in human skulls encompassing a broad range of subsistence practices and, presumably, tooth use. The skulls (Table 1) ranged from hunter-gatherers of the aboriginal New World (Eskimos, Ohio Woodland and Tennessee Archaic samples) to food producers of both the New and Old World (Southwestern Pueblo and Tennessee Mississippian samples; British AngloSaxons) to 17 th and early 20 th century samples from England and the United States. All were over 18 years of age, as assessed by known or assigned chronologi- cal ages, or by status of third molar eruption or closure of the spheno-occipital synchondrosis. Sex determinations were made, postcranially in most cases, by workers at the institutions listed in Table 1. Condylar breath was defined as the maximum distance between the most medial and most lateral points on the articular surface. Condylar length was defined as the maximum anterior-posterior distance on the articular surface near its midpoint. Area of the condylar articular surface was calculated as the product of condylar breadth and condylar length. Size of the temporal joint component in basal view was assessed by the following 3 measurements (Hinton and Carlson, 1979): (1) postglenoid process (PGP) to articular tubercle (AT) distance; (2) postglenoid process (PGP) to temporal spine (TS) (the junction of the squamosal suture and the tympanosquamosal fissure) distance: (3) temporal spine (TS) to articular tubercle (AT) distance. Size of the mandibular fossa was estimated as the area of the joint triangle defined by these measurements. In order to assess the influence of overall craniofacial size on MJ size. selected cranial dimensions were measured: maximum cranial length, maximum cranial breadth, bizygomatic breadth, bicondylar breadth, cranial height and upper facial height.

Two groups, Eskimo and American caucasoid, were selected for analysis, based on the extremes of joint size, craniofacial size and tooth use which they represent and on the large number of specimens in the groups. The 6 cranial dimensions measured in those groups sampled were subjected to a principal-components analysis: an individual's score for the first principal component. which accounted for 53.8 per cent of the total variance, was taken as an indication of overall craniofacial size. Differences in relative joint size between the two groups (that is, comparative joint size when craniofacial size is taken into account) were then investigated using analysis of co-variance to test for group differences between means adjusted for the co-variate (score on the first principal component).

Table 1. Sizes, dates and location of human skeletal samples

\begin{tabular}{|c|c|c|c|}
\hline Sample & $n$ & Dates & Location \\
\hline Eskimo & 195 & $\begin{array}{l}\text { Late } 18 \text { th-early } 20 \text { th } \\
\text { century; } 12 \text { th century }\end{array}$ & $\begin{array}{l}\text { Smithsonian Institution; } \\
\text { Arizona State University }\end{array}$ \\
\hline Ohio Woodland & 129 & AD $800-1100$ & Kent State University \\
\hline $\begin{array}{l}\text { Tennessee Indians, } \\
\text { Archaic period }\end{array}$ & 106 & $6000-500 \mathrm{BC}$ & University of Tennessee \\
\hline $\begin{array}{l}\text { Tennessee Indians, } \\
\text { Mississippian period }\end{array}$ & 118 & AD $1300-1550$ & University of Tennessee \\
\hline $\begin{array}{l}\text { Pueblo Indians, } \\
\text { Southwestern U.S. }\end{array}$ & 248 & $\mathrm{AD} 1280-1600$ & $\begin{array}{l}\text { Arizona State Museum; } \\
\text { Arizona State University }\end{array}$ \\
\hline Anglo-Saxons & 102 & AD $650-950$ & $\begin{array}{l}\text { British Museum (Natural } \\
\text { History), London }\end{array}$ \\
\hline American caucasoid & 162 & Early 20th century & $\begin{array}{l}\text { Smithsonian Institution } \\
\text { Cleveland Museum of } \\
\text { Natural History }\end{array}$ \\
\hline 17th Century British & 61 & 17th Century & $\begin{array}{l}\text { Duckworth Laboratory } \\
\text { Cambridge University }\end{array}$ \\
\hline
\end{tabular}

For further information concerning the samples, see Hinton $(1981 \mathrm{~b}, \mathrm{c})$. 


\section{RESULTS}

Differences in absolute joint size

Mean joint dimensions (Tables 2 and 3 ) in the North American aboriginal samples are in virtually every instance larger than the corresponding values in 20 th century caucasoids or in the British. This disparity is least pronounced in comparisons with preMedieval Anglo-Saxons. The difference in joint size between aboriginal and American caucasoid or 17th centur y British is most marked. on a relative basis, for condylar length. The female means in certain of the aboriginal groups (most notably, the hunter-gatherers) are equal to or greater than the male means in the American caucasoid and British for a number of measurements. The means among the aboriginal groups display a distinct size hierarchy, with huntergatherers (Eskimos, Ohio Woodland and Tennessee Archaic Indians) having appreciably larger joints than groups depending partly or completely on horticulture (Tennessee Indians, Mississippian period; Pueblo Indians from Southwestern United States)

\section{Differences in joint size relative to craniofacial size}

In virtually every instance, Eskimo joint dimen- sions, adjusted for differences in overall craniofacial size, were significantly $(p<0.001)$ larger than those in American caucasoids (Table 4). Selected depictions of these data (Figs 1-4) illustrate the magnitude of intergroup differences, which were especially pronounced for condylar length. By contrast, similar comparisons of relative joint size between males and females within groups (Table 5, Figs 1-4) demonstrate much less clear-cut differences. For a number of dimensions, females are as large or larger (significantly so in some cases) than males when means are standardized for overall craniofacial size. The main exception was for condylar breadth, in which males were significantly larger. Comparison of adjusted mean values for Eskimo females and American caucasoid males (Table 4. Figs 1-4) demonstrates that Eskimo females were significantly larger in every instance. with the exception of condylar breadth.

\section{DISCUSSION}

The data demonstrate considerable variation in size of the $\mathrm{MJ}$ among recent and aboriginal human groups. Furthermore, differences in mean values between

Table 2. Comparative MJ dimensions in North American aboriginal, American caucasoid and British samples: males

\begin{tabular}{|c|c|c|c|c|c|c|c|c|}
\hline Sample & & $\begin{array}{c}\text { Condylar } \\
\text { length }\end{array}$ & $\begin{array}{c}\text { Condylar } \\
\text { breadth }\end{array}$ & $\begin{array}{c}\text { Condylar } \\
\text { area }\end{array}$ & PGP-TS & PGP-AT & TS-AT & $\begin{array}{c}\text { Mandibular } \\
\text { fossa } \\
\text { area }\end{array}$ \\
\hline \multirow[t]{3}{*}{ Eskimo } & Mean & 10.3 & 21.8 & 226.8 & 18.4 & 18.7 & 27.1 & 171.1 \\
\hline & $\mathrm{SD}$ & 1.1 & 1.6 & 31.1 & 1.7 & 1.9 & 1.7 & 23.1 \\
\hline & $n$ & 104 & 100 & 100 & 109 & 109 & 109 & 109 \\
\hline Ohio Indians, & Mean & 8.6 & 21.5 & 184.4 & 20.3 & 17.5 & 27.0 & 176.7 \\
\hline \multirow[t]{2}{*}{ Woodland } & SD & 0.9 & 1.6 & 27.9 & 1.8 & 1.4 & 1.7 & 20.6 \\
\hline & $n$ & 38 & 33 & 33 & 64 & 65 & 64 & 64 \\
\hline Tennessee & Mean & 9.1 & 21.5 & 2009 & 20.0 & 17.2 & 27.0 & 170.9 \\
\hline \multirow{2}{*}{ Indians, Archaic } & SD & 0.9 & 1.8 & 27.7 & 1.7 & 1.6 & 1.6 & 22.3 \\
\hline & $n$ & 49 & 31 & 31 & 60 & 60 & 61 & 60 \\
\hline Tennessee & Mean & 8.3 & 20.2 & 166.6 & 18.7 & 16.8 & 25.4 & 156.1 \\
\hline \multirow[t]{2}{*}{ Indians, Mississippian } & $\mathrm{SD}$ & 0.8 & 1.8 & 27.9 & 1.8 & 1.4 & 1.9 & 17.8 \\
\hline & $n$ & 49 & 41 & 41 & 64 & 62 & 62 & 62 \\
\hline Pueblo Indians, & Mean & 9.2 & 19.6 & 181.9 & 18.5 & 17.1 & 25.4 & 158.9 \\
\hline \multirow[t]{2}{*}{ Southwest U.S. } & SD & 1.0 & 2.1 & 32.3 & 2.3 & 1.7 & 1.7 & 20.3 \\
\hline & $n$ & 96 & 90 & 90 & 109 & 108 & 107 & 105 \\
\hline \multirow[t]{3}{*}{ Anglo-Saxons } & Mean & 8.2 & 21.5 & 176.4 & 17.6 & 17.7 & 25.8 & 154.4 \\
\hline & $\mathrm{SD}$ & 1.1 & 1.6 & 29.3 & 1.7 & 1.8 & 1.6 & 19.3 \\
\hline & $n$ & 47 & 41 & 41 & 53 & 53 & 53 & 53 \\
\hline \multirow[t]{3}{*}{ American caucasoid } & Mean & 7.8 & 20.3 & 159.4 & 17.5 & 17.3 & 24.8 & 149.2 \\
\hline & $\mathrm{SD}$ & 1.1 & 1.8 & 28.2 & 1.8 & 1.7 & 1.8 & 19.0 \\
\hline & $n$ & 102 & 101 & 101 & 105 & 105 & 105 & 105 \\
\hline \multirow[t]{3}{*}{ 17th Century British } & Mean & 7.6 & 19.8 & 149.7 & 17.3 & 16.2 & 24.1 & 139.5 \\
\hline & $\mathrm{SD}$ & 0.8 & 1.6 & 22.9 & 1.4 & 1.5 & 1.6 & 18.4 \\
\hline & $n$ & 49 & 47 & 47 & 37 & 37 & 37 & 37 \\
\hline
\end{tabular}

All means are in millimeters, except for condylar area and mandibular fossa area which are in square millimeters.

Onc way analysis of variance showing that Eskimo means arc significantly $(p<0.001)$ greater than those of other groups in nearly every instance; significant differences between other hunter-gatherer, horticultural and more recent groups are present for all dimensions studied. In general, and particularly for condyl and mandibular fossa differences among group means correspond to subsistence patterns: hunter-gathercrs comprise a cluster, not significantly different from each other but significantly different from horticulturalists, which form a cluster significantly different from the British and American caucasoid groups. 
Table 3. Comparative MJ dimensions in North American aboriginal, American caucasoid and British samples: females

\begin{tabular}{|c|c|c|c|c|c|c|c|c|}
\hline Sample & & $\begin{array}{l}\text { Condylar } \\
\text { length }\end{array}$ & $\begin{array}{l}\text { Condylar } \\
\text { breadth }\end{array}$ & $\begin{array}{c}\text { Condylar } \\
\text { area }\end{array}$ & PGP-TS & PGP-AT & TS-AT & $\begin{array}{c}\text { Mandibular } \\
\text { fossa } \\
\text { area }\end{array}$ \\
\hline \multirow[t]{3}{*}{ Eskimo } & Mean & 9.3 & 19.4 & 181.5 & 17.5 & 18.4 & 25.4 & 160.0 \\
\hline & SD & 1.1 & 1.7 & 30.8 & 1.9 & 1.7 & 1.9 & 22.3 \\
\hline & $n$ & 77 & 73 & 72 & 86 & 86 & 86 & 86 \\
\hline Ohio Indians & Mean & 8.4 & 20.1 & 167.8 & 19.1 & 17.3 & 25.6 & 163.6 \\
\hline \multirow[t]{2}{*}{ Woodland } & $\mathrm{SD}$ & 0.9 & 1.7 & 23.1 & 1.6 & 1.4 & 1.6 & 15.0 \\
\hline & $n$ & 39 & 35 & 35 & 64 & 64 & 64 & 64 \\
\hline Tennessee & Mean & 8.7 & 18.9 & 163.6 & 19.0 & 16.6 & 25.3 & 156.3 \\
\hline \multirow[t]{2}{*}{ Indians, Archaic } & SD & 0.8 & 1.4 & 18.1 & 1.6 & 1.3 & 1.5 & 16.5 \\
\hline & $n$ & 32 & 25 & 25 & 42 & 41 & 41 & 40 \\
\hline Tennessee & Mean & 8.0 & 18.4 & 147.3 & 18.3 & 15.7 & 24.0 & 143.3 \\
\hline \multirow[t]{2}{*}{ Indians, Mississippian } & $\mathrm{SD}$ & 1.0 & 1.8 & 23.6 & 1.6 & 1.5 & 1.2 & 13.5 \\
\hline & $n$ & 35 & 27 & 27 & 46 & 45 & 45 & 45 \\
\hline Pueblo Indians, & Mean & 9.2 & 17.9 & 164.0 & 17.6 & 16.6 & 23.9 & 145.4 \\
\hline \multirow[t]{2}{*}{ Southwest U.S. } & SD & 1.0 & 1.8 & 26.7 & 1.6 & 1.5 & 1.7 & 16.0 \\
\hline & $n$ & 123 & 116 & 115 & 132 & 134 & 133 & 132 \\
\hline \multirow{3}{*}{ Anglo-Saxons } & Mean & 7.8 & 19.9 & 157.3 & 16.8 & 16.9 & 24.3 & 140.3 \\
\hline & SD & 1.0 & 1.8 & 23.5 & 1.7 & 1.5 & 1.5 & 15.1 \\
\hline & $n$ & 45 & 39 & 39 & 49 & 49 & 49 & 49 \\
\hline \multirow[t]{3}{*}{ American caucasoid } & Mean & 7.6 & 17.9 & 135.7 & 16.4 & 16.6 & 23.3 & 135.1 \\
\hline & SD & 1.0 & 1.8 & 22.3 & 1.7 & 1.8 & 1.5 & 17.9 \\
\hline & $n$ & 57 & 57 & 57 & 57 & 57 & 57 & 57 \\
\hline \multirow[t]{3}{*}{ 17th Century British } & Mean & 7.3 & 18.0 & 1319 & 16.1 & 16.8 & 23.0 & 134.4 \\
\hline & SD & 0.8 & 2.2 & 24.7 & 1.7 & 1.1 & 09 & 12.7 \\
\hline & $n$ & 33 & 32 & 32 & 24 & 24 & 24 & 24 \\
\hline
\end{tabular}

Table 4. Test for equality of adjusted means*: intergroup comparisons

\begin{tabular}{|c|c|c|c|c|c|}
\hline Variable & $\begin{array}{c}\text { Eskimo } \\
\text { adjusted } \\
\text { mean }\end{array}$ & $\begin{array}{c}\text { American } \\
\text { adjusted mean }\end{array}$ & d.f. & F-statistic & Significance \\
\hline \multicolumn{6}{|c|}{ Eskimo males versus American caucasoid males } \\
\hline PGP-AT distance & 18.2 & 17.7 & $(1,171)$ & 2.43 & 0.1209 \\
\hline TS-AT distance & 26.8 & 25.2 & $(1,171)$ & 24.91 & 0.0000 \\
\hline Condylar breadth & 21.5 & 20.7 & $(1,171)$ & 7.18 & 0.0081 \\
\hline Condylar length & 10.0 & 8.1 & $(1,171)$ & 99.98 & 0.0000 \\
\hline Mandibular fossa area & 168.2 & 154.5 & $(1,171)$ & 13.16 & 0.0004 \\
\hline Condylar area & 216.5 & 167.5 & $(1,171)$ & 93.57 & 0.0000 \\
\hline \multicolumn{6}{|c|}{ Eskimo females versus American caucasoid females } \\
\hline PGP-AT distance & 18.3 & 17.0 & $(1,98)$ & 10.21 & 0.0019 \\
\hline TS-AT distance & 25.1 & 23.7 & $(1,98)$ & 15.01 & $0.0002 \dagger$ \\
\hline Condylar breadth & 19.1 & 18.4 & $(1,98)$ & 3.85 & 0.0526 \\
\hline Condylar length & 9.1 & 7.7 & $(1,98)$ & 30.31 & 0.0000 \\
\hline Mandibular fossa area & 158.1 & 140.8 & $(1,98)$ & 15.70 & 0.0001 \\
\hline Condylar area & 176.1 & 143.0 & $(1,98)$ & 35.08 & 0.0001 \\
\hline \multicolumn{6}{|c|}{ Eskimo females versus American caucasoid males } \\
\hline PGP-AT distance & 18.9 & 17.2 & $(1,140)$ & 36.30 & 0.0000 \\
\hline TS-AT distance & 25.8 & 24.7 & $(1,140)$ & 14.30 & 0.0002 \\
\hline Condylar breadth & 20.0 & 20.2 & $(1,140)$ & 0.50 & 0.4823 \\
\hline Condylar length & 9.5 & 7.8 & $(1,140)$ & 73.09 & 0.0000 \\
\hline Mandibular fossa area & 166.9 & 147.9 & $(1,140)$ & 33.24 & 0.0000 \\
\hline Condylar area & 188.8 & 157.4 & $(1,140)$ & 41.93 & 0.0000 \\
\hline
\end{tabular}

* Slopes for individual group regression lines are equal and non-zero except where noted. All means are in millimeters (linear dimensions) or square millimeters (area).

$\dagger$ Slopes of the two regression lines are different at $p \leqslant 0.0483$; due to the marginality of this value, the analysis was carried to completion. 


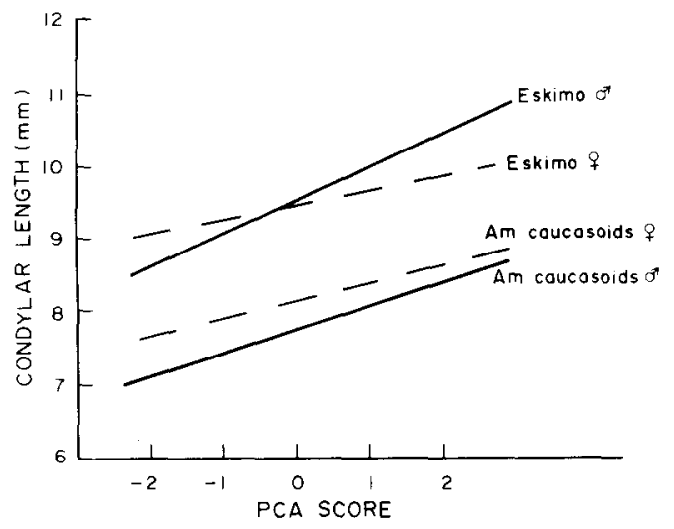

Fig. 1. Regression of condylar length on score for the first principal component for Eskimos and American caucasoids.

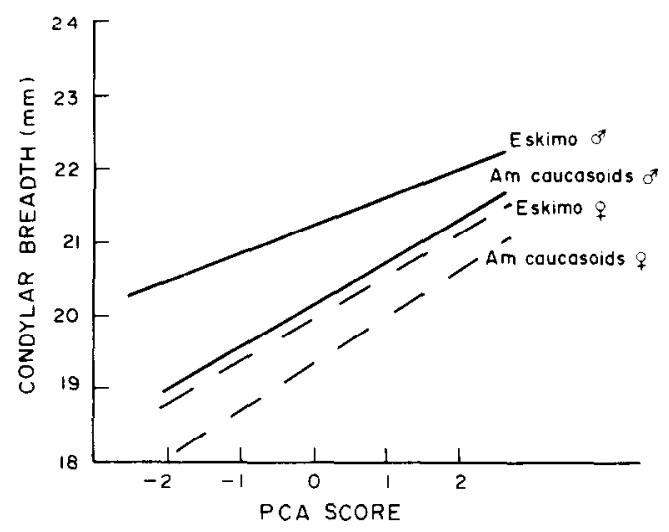

Fig. 2. Regression of condylar breadth on score for the first principal component for Fskimos and American caucasoids.



Fig. 3. Regression of condylar area on score for the first principal component for Eskimos and American caucasoids.

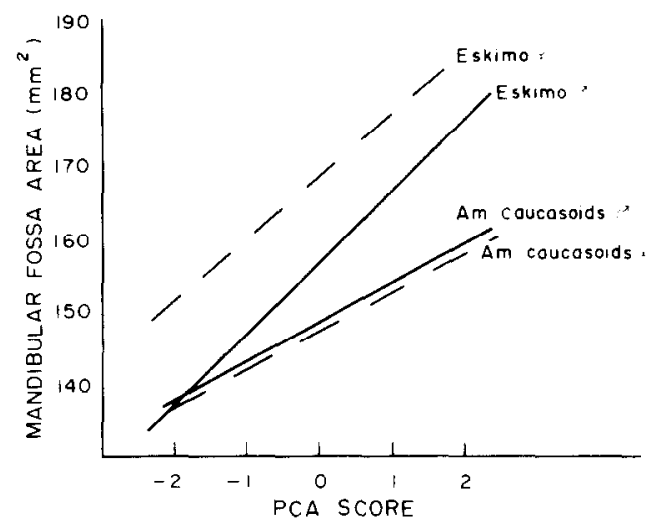

Fig. 4. Regression of mandibular fossa area on score for the first principal component for Eskimos and American caucasoids.

Table 5. Test for equality of adjusted means: within group comparisons

\begin{tabular}{|c|c|c|c|c|c|}
\hline Variable & $\begin{array}{l}\text { Male } \\
\text { adjusted } \\
\text { mean }\end{array}$ & $\begin{array}{l}\text { Female } \\
\text { adjusted } \\
\text { mean }\end{array}$ & d.f. & F-statistic & Significance \\
\hline \multicolumn{6}{|c|}{ Eskimo males versus Eskimo females } \\
\hline PGP-AT distance & 18.2 & 19.7 & $(1,120)$ & 9.60 & $0.0024 *$ \\
\hline TS-AT distance & 26.7 & 26.6 & $(1,120)$ & 0.00 & 0.9624 \\
\hline Condylar breadth & 21.6 & 26.6 & $(1,120)$ & 11.05 & 0.0012 \\
\hline Condylar length & 10.0 & 9.8 & $(1.120)$ & 0.53 & 0.4677 \\
\hline Mandibular fossa area & 166.9 & 178.0 & $(1,120)$ & 4.21 & $0.0422^{*}$ \\
\hline Condylar area & 217.0 & 201.8 & $(1,120)$ & 4.78 & 0.0308 \\
\hline \multicolumn{6}{|c|}{ Amcrican caucasoid males versus Amcrican caucasoid females } \\
\hline PGP-AT distance & 16.9 & 17,3 & $(1,149)$ & 1.47 & 0.2270 \\
\hline TS-AT distance & 24.4 & 23.9 & $(1,149)$ & 2.14 & 0.1453 \\
\hline Condylar breadth & 19.7 & 18.9 & $(1,149)$ & 4.99 & 0.0270 \\
\hline Condylar length & 7.6 & 7.9 & $(1,149)$ & 1.58 & 0.2106 \\
\hline Mandibular fossa area & 144.5 & 143.4 & $(1,149)$ & 0.07 & 0.7863 \\
\hline Condylar area & 151.2 & 149.6 & $(1,149)$ & 0.07 & 0.7802 \\
\hline
\end{tabular}

* Females larger. 
groups are highly patterned; hunter-gatherers have larger joint dimensions than agriculturalists, and industrialized American caucasoids and 17th century British have the smallest mean values. The view that intergroup differences in joint size may be related in part to different patterns of tooth use is given circumstantial support by the large joint dimensions in hunter-gatherers from widely separated regions of North America, and by the occurrence of similarly reduced $\mathrm{MJ}$ size in populations relying on a more easily masticated diet of cultigens in both North America (Tennessee Indians of Mississippian period) and Europe (Anglo-Saxons).

Sex dimorphism in joint size was present in every group, in agreement with work by Martin (1936), Morant (1936) and Lindblom (1960). However, the data of Table 5 suggest that the difference may be primarily one of absolute size. For the most part. male joint dimensions are not relatively larger than those in females, when corrected for craniofacial size. The main exception to this generalization is condylar breadth which appears to be consistently larger in males throughout the range of craniofacial size. The meaning of this finding is unclear. Wedel et al. (1978) concluded that condylar breadth reflects the influence of orofunctional demands based on its positive correlations to jaw dimensions. However, as males generally have larger jaws than females, this assertion is consistent with my data. At the same time. Eskimo females (Table 4 and Figs 1-4) have significantly larger dimensions for most joint measures than American caucasoid males. Interestingly, the single dimension in which Eskimo females are not larger is condylar breadth. As strenuous tooth-use and craniofacial muscularity are probably greater in Eskimo females than in American caucasoid males, it may be that condylar breadth is less sensitive than other aspects of joint size to orofunctional influences.

Perhaps the most interesting finding is that $\mathrm{MJ}$ size is not only absolutely but relatively larger in an aboriginal group (Eskimos) than in a recent group from an industrialized society (American caucasoid). That this difference relates to factors other than cranial size is underscored by the existence of larger dimensions for most joint measures in Eskimo females than in American caucasoid males, groups which have similar ranges of craniofacial size variation. The extent to which these intergroup differences in joint size are due to the influences of genetic factors or functional demands during growth cannot be assessed from these data.

There is appreciable evidence that the nature and intensity of orofunctional activities in aboriginal human groups (especially the Eskimo) differed considerably from that in more recent western societies. as attested by ethnographic accounts (DePoncins, 1941; Gould, 1968; Lous, 1970; Molnar 1972), comparative bite force data (Waugh, 1937; Heath, 1948; Neuman and DiSalvo, 1959; Linderholm and Wennstrom, 1970) and studies of dental attrition (Pedersen, 1949; Anderson, 1965; Merbs, 1968; Turner and Cadien, 1969; Hylander, 1977). Although little is known of the influence of genetic factors on MJ size, comparison of joint size in time-successive, genetically contiguous human groups which differ in mode of subsistence offers some possibility of identifying genetic and functional aspects of variation. There are secular trends in joint size reduction in populations undergoing the transition from hunter-gathering to sedentary agriculture in Africa (Hinton and Carlson, 1979) and in North Anerica (Corruccini and Handler, 1980; Hinton, 1981c). In each instance, the changes in joint size were accompanied by indications of reduced demands on the masticatory system (Hinton, 1982). Thus, there are circumstantial reasons for believing that the intergroup differences I found are at least partly attributable to differences in oral function.

Acknowledgements-The following individuals and institutions kindly provided access to material: Dr P. Parmalee, McClung Museum, University of Tennessee (Knoxville): Dr D. Ubelaker, Smithsonian Institution; Dr W. Birkby, Arizona State Museum. University of Arizona (Tucson) Drs C. Merbs and C. Turner, Arizona State University (Tempe); Dr D. Johanson. Cleveland Mueseum of Natural History: Dr O. Lovejoy. Kent State University: $\mathrm{Dr} C$ Stringer. Miss Rosemary Powers, and Mr R. Kruszynski, British Museum (Natural History); Dr J. Garlick and Mr B. Denston, Duckworth Laboratory, Cambridge University. Portions of this research were supported by National Science Foundation Dissertation improvement Grant BNS78-07331, a Rackham School of Graduate Studies Dissertation Grant (University of Michigan) and a Hilton A. Smith Postdoctoral Fellowship (Department of Anthropology. University of Tennessee, Knoxville).

\section{REFERENCES}

Anderson J. E. 1965. Human skeletons from Tehuacan Science 148, 496-497.

Barbenel J. C. 1969. Analysis of forces at the temporomandibular joint during function. Dent. Practur. dent. Rec. 19, 305310

Barbenel J. C. 1972. The biomechanics of the temporomandibular joint: a theoretical study. $J$. Biomech. 5, 251-256.

Barber C. G., Green L. J. and Cox G. J. 1963. Effects of the physical consistency of diet on the condylar growth of the rat mandible. J. dent. Res, 42, 848-851.

Beecher R. M. and Corruccini R. S. 1981. Effects of dietary consistency on craniofacial and occlusal development in the rat. Angle Orthod. 51, 61-69.

Carlson D. S.. MeNamara Jr J. A. and Jaul D. H. 1978. Histological analysis of the growth of the mandibular condyle in the rhesus monkey (Macaca mulatta). Am. J. Anat. 151, 103-118.

Corruccini R. S. and Handler J. S. 1980. Temperomandibular joint size decrease in American Blacks: evidence from Barbados. J. dent. Res. 59, 1528.

Demirjian A. 1967. A study of the morphology of the glenoid fossa. Natn. Mus. Canada Bull. 206, 1-25.

DePoncins G. 1941. Kabloona. Reynal and Hitchcock. New York.

Dingwall D. and Young M. 1933. The skulls from excavations at Dunstable. Bedfordshire. Biometrika 25, 147 157.

Gould R. A. 1968. Chipping stones in the outback. Nat. Hist. 77, 42-49.

Granados J. I. 1979. The influence of the loss of teeth and attrition on the articular eminence. J. prosth. Dent. 42 , $78-85$.

Heath J. 1948. Facial form and biting pressure. Aust. J. Dent. 31, 303-312.

Hinton R. J. 1981a. Form and function in the temporomandibular joint. In: Craniofacial Biology (Edited by Carlson D. S) pp. 37-60. Monogr. No. 10, Craniofacial Growth Series, Center for Human Growth and Development, Ann Arbor, Michigan. 
Hinton R. J. 1981b. Changes in articular eminence morphology with dental function. Am. J. phys. Anthrop. 54, $439-455$.

Hinton R. J. 1981c. Temporomandibular joint size adaptations in prehistoric Tennessee Indians. Tenn. Anthrop. 6. $89-111$.

Hinton R. J. 1982. Differences in interproximal and occlusal tooth wear among prehistoric Tennessee Indians: implications for masticatory function. Am. J. Phys. Anthrop. 57, 103-115.

Hinton R. J. and Carlson D. S. 1979. Temporal changes in human temporomandibular joint size and shape. $A m$. $J$ phys. Anthrop. 50, 325-334.

Hylander W. L. 1975. The human mandible: lever or link? Am. J. phrs. Anthrop. 43, 227 242.

Hylander $\dot{W}$. L. 1977. The adaptative significance of Eskimo craniofacial morphology. In: Orofacial Growth and Development (Edited by Dahlberg A. A. and Graber T. M.) pp. 129-170. Mouton. The Hague.

Hylander W. L. 1979. An experimental analysis of temporomandibular joint reaction force in macaques. $\mathrm{Am} . \mathrm{J}$. phys. Anthrop. 51, 433-456.

Kazanjian V. H. 1939. Congenital absence of the ramus of the mandible. J. Bone Jt Surg. 21, 761-772.

Lindblom G. 1960. On the Anatomy and Function of the Temporomandibular Joint. AB Fahlcrantz' Boktryckeri. Stockholm.

I indlom (i. 1976. Observations on normal and abnormal temporomandibular joint function. In: Mastication (Edited by Anderson D. J. and Matthews B.) pp. 131 137. Wright, Bristol.

Linderholm $\mathrm{H}$. and Wennstrom A. 1970. Isometric bite force and its relation to general muscle force and body build. Acta odont. scand. 28, 679-689

Lous I. 1970. The masticatory system used as a tool. Dent. Abstr. 15, 457. 458.

Martin E. S. 1936. A study of an Egyptian series of mandibles. with special reference to mathematical methods of sexing. Biometrika 28, 149-178.

McNamara Jr J. A. 1972. Neuromuscular and Skeletal Adaptations to Altered Orofacial Function. Monogr. No. 1, Craniofacial Growth Series, Center for Human Growth and Development. Ann Arbor, Michigan.

McNamara Jr J. A. and Carlson D. S. 1979. Quantitative analysis of temporomandibular joint adaptations to protrusive function. Am. J. Orthodont. 76, 53-61.

Merbs C. F. 1968. Anterior tooth loss in arctic populations. SWest. J. Anthrop. 24, 20-32.

Moffett B. C. 1966. The morphogenesis of the temporomandibular joint. Am. J. Orthodont. 52, 401-415.

Moffett B. C. 1968. The temporomandibular joint. In: Complete Denture Prosthodontics, 2nd edn (Edited by Sharry J. J. pp. 56-104. McGraw-Hill, New York.

Moffett B. C. Johnson L. C. McCabe J. B. and Askew H. C. 1964. Articular remodeling in the adult tempormandibular joint. Am. J. Anat. 115, 119-142.

Molnar S. 1972. Tooth wear and culture: a survey of tooth functions among some prehistoric populations. Curr. Anhrop. 13, 511-526.

Mongini F. 1972. Remodelling of the mandibular condyle in the adult and its relationship to the condition of the dental arches. Acta anat. 82, 437-453

Moore W. J. 1965. Masticatory function and skull growth. J. Zool. 146, 123-131

Morant G. M. 1936. A biometric study of the human mandible. Biometrika 28, $84 \cdot 122$.

Neuman H. N. and DiSalvo N. H. 1959. Caries in the Indians of the Mexican Cordillera, the Peruvian Andes, and the Amazon headwaters. Br. dent. J. 104, 13-16.

Oberg T., Carlsson G. E. and Fajers C.-M. 1971. The temporomandibular joint. A morphologic study on a human autopsy material. Acta odont. scand. 29, 349 384.

Pedersen P. O. 1949. The East Greenland Eskimo Dentition Medd. Gronland 142.

Petrovic A. G., Stutzmann J. J. and Oudet C. L. 1975 Control processes in the postnatal growth of the condylar cartilage of the mandible. In Determinants of Mandibular Growth and Form (Edited by McNamara Jr J. A. ) pp. 101..154. Monogr. No. 4. Craniofacial Growth Series. Center for Human Growth and Development. Ann Arbor, Michigan.

Radin E. L., Simon S. R.. Rose R. M. and Paul I. L. 1979. Practical Biomechanics for the Orthopedic Suryem. Wiley, New York.

Rees L. A. 1954. The structure and function of the mandibular joint. $\mathrm{Br}$. dent. J. 96, 125 133

Rushton M. A. 1944. Growth at the mandibular condyle in relation to some deformities. Br. dent. J. 76, 57-68.

Scheman P.. Milstoc M. and Rubin M. 1974. T.M.J. trabeculation as an expression of joint function. V.Y. St. dent. J. 40, 595600

Scott J. H. and Symons N. B. B. 1974. Introduction to Dental Anatomy. Churchill Livingstone. Edinburgh.

Seward F. S. 1976. Tooth attrition and the temporomandibular joint. Angle Orthod. 46, 162-170.

Sicher H. 1952. Functional andomy of the temporomandibular articulation. Dent. J. Aust. 24, 114.

Simon M. R. 1977. The role of compressive forces in the normal maturation of the condylar cartilage of the rat. Acta anat. 97, 351-360

Smith F. H. 1976. The Neanderthal Remains from Krapina: $A$ Descriptive and Comparative Study. Univ. of Tennessee Department of Anthropology Report of Investigations No. 15

Smith R. J. 1978. Mandibular biomechanics and temporomandibular joint function in primates. Am. J. phys. Anthrop. 49, $341-350$.

Stockli P. W. and Willert H. G. 1971. Tissue reactions in the temporomandibular joint resulting from anterior displacement of the mandible in the monkey. Am. J. Orthodont. 60, 142-155

Turner Il C. G. and Cadien J. D. 1969. Dental chipping in Aleuts Eskimos, and Indians. Am. J. phis. Anthrop. 31, $303-310$.

Van Zile W. N. 1954. Unilateral hyperplasia of the mandibular condyle, J. oral Surg. 12, 275-283.

Wallace J. S. 1927. Variation in the Form of the Jaws. Bailliere. Tindall and Cox. London.

Watı P. G. and Williams H. M. 1951. The ellects of the physical consistency of food on the growth and development of the mandible and maxilla of the rat. $4 \mathrm{ml} . J$. Orthodont. 37, 895-928.

Waugh L. M. 1937. Dental observations among Eskimos. J. dent. Res. 16, 355-356.

Wedel A.. Carlsson G. E. and Sagne S. 1978. Temporomandibular joint morphology in a medieval skull material Swed. dent. J. 2, 177-187.

Weidenreich F. 1936. The mandibles of Sinanthropus pekinensis. Palaeont. Sin. D 4, $1-162$

White T. D. 1977. The Anterior Mandibular Corpas of Early African Hominidae: Functional Significance of Shape and Size. Unpublished doctoral dissertation. Univ. of Michigan, Ann Arbor

Wolfpoff M. H. 1975. Some aspects of human mandibular evolution. In Determinants of Mandibular Form and Growth (Edited by McNamara Jr J. A.) pp. 164 Monogr. No. 4, Craniofacial Growth Series. Center for Human Growth and Development. Ann Arbor. Michigan.

Wright D. M. and Moffett B. C. 1974. The postnatal development of the human temporomandibular joint. Am. $J$ Anat 141, 235-250. 